\title{
OS “REFUGIADOS” HAITIANOS E A INTERVENÇÃO JUDICIAL PARA A GARANTIA DOS DIREITOS FUNDAMENTAIS
}

\section{Jorge Luiz Oliveira dos Santos ${ }^{1}$ Luiz Renato de Souza Melo ${ }^{2}$}

\section{Resumo}

O presente artigo se propõe analisar a qualidade de "refugiados" dos haitianos que estão no Brasil frente ao Estatuto dos Refugiados de 1951, bem como à Lei Pátria no 9.474/97, perpassando pelo estudo do direito de ir e vir e a possibilidade de intervenção judicial, através de ações coletivas, para a garantia dos direitos mínimos a viverem com dignidade.

Palavras-chave: Movimentos migratórios. Direito de ir e vir. Refugiados. Direitos Fundamentais. Mínimo existencial.

\section{INTRODUÇÃO}

Um tema bastante discutido quando se trata de mobilidade humana internacional não é tão somente a possível antinomia existente entre o reconhecimento do direito humano fundamental de ir e vir e a soberania estatal para o controle de suas fronteiras, mas, principalmente, a efetivação dos direitos fundamentais sociais supostamente conferidos àquela classe de deslocados aquando de sua recepção/acolhimento.

A circulação de pessoas através dos territórios não nos é novidade, muito pelo contrário, a história destas movimentações migratórias confunde-se com a própria história humana, pois o homem sempre buscou explorar novos territórios com o objetivo de melhorar suas inquietações sociais, culturais, econômicas.

Os tais estrangeiros/"forasteiros" circulando por "terras alheias" já são mencionados desde a Bíblia, em que pese tal fenômeno seja muito anterior a estes escritos. A primeira em Êxodo, capítulo 22, versículo 21, aduz: "Não molestarás nem afligirás o estrangeiro, porque também vós fostes estrangeiro na terra do Egito. Em uma

\footnotetext{
${ }^{1}$ Doutor em Ciências Sociais (Antropologia) pelo Programa de Pós-Graduação em Ciências Sociais da Universidade Federal do Pará (PPGCS/UFPA). Professor-Pesquisador na Universidade da Amazônia (Unama), PA. E-mail: jorgeluiz_dossantos@hotmail.com

${ }^{2}$ Mestrando no Programa de Mestrado em Direitos Fundamentais da Universidade da Amazônia (2015/2016). Professor na graduação do curso de Direito na Faculdade Integrada Brasil Amazônia. Professor do curso de Especialização em Direito Processual e Direito Material e Processual do Trabalho da Faculdade Maurício de Nassau e Ordem dos Advogados do Brasil, Seção Pará. E-mail: luiz_renato_melo@yahoo.com.br
} 
segunda passagem em Levítico, capítulo 19, versículo 33: "Se algum estrangeiro habitar na vossa terra, e morar entre vós, não o impropereis; mas esteja entre vós como um natural; amai-o como a vós mesmo, porque também vós fostes estrangeiro na terra do Egito".

Ou ainda em Mateus, capítulo 25, versículo 35: "Eu era estrangeiro e você me acolheu".

Os movimentos migratórios sempre apresentaram causas de ordem natural, econômica e/ou social, estas, atualmente, as mais preponderantes: cataclismos, desastres naturais, fome, perseguições políticas e religiosas, perspectiva de encontrar uma vida mais abastarda, dentre outros anseios trazidos por estes migrantes.

Hodiernamente, algumas movimentações migratórias vêm despertando grande preocupação internacional, talvez não fosse visto tão grande deslocamento de pessoas desde a segunda grande guerra mundial.

Os imigrantes que fogem da Nigéria, Eritréia e Líbia para cruzar o Mar Mediterrâneo, passando pela ilha de Lampedusa e chegar à Itália; outra rota parte do Oriente Médio da Síria, Paquistão e Afeganistão em direção à Grécia e Macedônia, na tentativa de chegarem aos países mais ricos como Alemanha, França e Inglaterra; no continente americano, o grande fluxo migratório vem da América Central, mais precisamente do Haiti, onde passam pelo Equador e Peru, até cruzar a fronteira do Brasil, pela cidade de Brasileia, no Acre e/ou Tabatinga, no Amazonas.

Embora estejam circulando/fugindo por motivos diversos, tendo em vista que nos dois primeiros casos se dão pela pobreza, fome, terrorismo e violência do país que deixam para trás, o que ocorre Brasil é o resultado da tentativa desesperada de fugir do país considerado o mais pobre da América e que fora arrasado por catástrofes naturais (terremoto de janeiro/2010 e furacão Sandy em novembro/2012).

A questão não é o simples acolhimento pelo país que recebe os imigrantes face ao direito humano direito fundamental, pois encontra-se em norma positivada fundamental de ir e vir - o que por si só já acarreta graves problemas estruturais com o crescimento inesperado da população local -, mas além de um pedaço de terra, um porto seguro, necessário se faz um olhar mais atento para as condições de vida que enfrentarão e, no presente caso, tal discussão voltar-se-á única e exclusivamente ao Brasil, a fim de observarmos à garantia aos direitos mínimos previstos na Constituição da República de 1988.

O artigo 1º, inciso III, da Constituição da República, assinala a dignidade da pessoa humana como pilar do Estado Democrático de Direito e é nessa norma constitucional que se assenta a unidade do ordenamento jurídico brasileiro.

Dignidade da pessoa humana, direito humano fundamental este garantido aos nacionais e aos estrangeiros que aqui residem (caso dos haitianos que aqui estão) indistintamente pelo art. $5^{\circ}$, caput, da CF/88:

Todos são iguais perante a lei, sem distinção de qualquer natureza, garantindo-se aos brasileiros e aos estrangeiros residentes no País a inviolabilidade do direito à vida, à liberdade, à igualdade, à segurança e à propriedade.

Partindo da premissa da dignidade da pessoa humana como direito fundamental mínimo e essencial vol.09, no. 04, Rio de Janeiro, 2016. pp. 1824-1840 
para que qualquer pessoa nacional ou não, possa "viver como gente" - frisa-se viver e não sobreviver - não seria necessária Lei infraconstitucional ou qualquer outro mecanismo (intervenção judicial) para assegurar sua observância, visto que seria inerente à condição de ser humano e todos seriam titulares.

Mínimo existencial que não se limitaria a aspectos humanitários na recepção em nosso território, mas que se refletiria em assegurar as garantias fundamentais à vida, liberdade, segurança, etc., bem como nos direitos sociais, econômicos e culturais, previstos na Constituição Federal, estes os mais básicos, essenciais e vitais como o trabalho, alimentação, educação, saúde, moradia, dentre outros.

Mais que isso, um dos objetivos fundamentais da República Federativa do Brasil é "promover o bem de todos, sem preconceito de origem, raça, sexo, cor, idade e quaisquer outras formas de discriminação", consoante o vaticinado pelo art. $3^{\circ}$ da Carta Magna de 1988.

Necessário se faz ainda a análise do deslocamento dos haitianos e seu acolhimento no Brasil com base nas normas internacionais, mais precisamente na Declaração Universal dos Direitos do Homem (1948) e Estatuto dos Refugiados (1951), bem como na legislação pátria através das Leis nos 9.474/97 e 11.961/2009, para que se possa verificar a possibilidade da concessão de "refúgio" nos moldes como vem sendo praticado.

\section{MOVIMENTOS MIGRATÓRIOS: SITUAÇÃO CONTEXTUAL E PROBLEMÁTICA ATUAL}

Segundo João Peixoto (2004), a história disciplinar das teorias sobre as migrações é, em vários aspectos, atribulada. O tema das migrações foi largamente ignorado pelos autores clássicos das principais ciências sociais, no período histórico em que estas se constituíram e consolidaram. A despeito da importância que os fluxos migratórios assumiram no final do século XIX e início do XX o tema não surge senão de forma marginal na maioria dos autores.

Assim, é possível dizer que a bibliografia sobre migrações partilha referências múltiplas, tanto as que provêm de diferentes disciplinas do social como as que envolvem os próprios debates internos da Sociologia.

Por um viés interdisciplinar, depreende-se que em qualquer época, a vida dos imigrantes nos países de acolhimento conheceu dificuldades. Nem sempre a chegada aos países escolhidos é tranquila. Basta pensar, como sugere Maria João Guia (2008), na criminalidade ligada à imigração, no auxílio à imigração ilegal, no tráfico de pessoas, no lenocínio, na angariação de mão de obra ilegal, na falsificação de documentos, nas redes dedicadas ao aliciamento e à exploração de imigrantes.

Autores como Marilda Aparecida de Menezes e Emilia Pietrafiesa Godoi (2011) e Ana Cristina Braga Martes (1999) admoestam que dentre as teias sociais que constituem os trânsitos migratórios, as práticas de entreajuda revelam-se fundamentais, quer se sobrepondo ou estando em paralelo com as formas de agenciamento 
do Estado ou mesmo com as redes ilegais que emergem neste universo, estas relações de suporte são um eixo vital da circulação que compõe a dinâmica da migração, enquanto fato coletivo e itinerário individual.

Para Simone Frangella (2014), seja na busca por novas formas de reprodução econômica familiar, ou por "sair pelo mundo" procurando vivências sociais de ordens diversas, os migrantes criam trajetórias condicionadas por trocas, favores e interações.

No debate sobre mobilidade migratória transnacional, de acordo com Alejandro Portes (2006), essa se traduz na movimentação de atores não institucionais que atravessam uma ou mais fronteiras nacionais, geográficas, culturais e políticas, e criam experiências pessoais e coletivas heterogêneas frente às assimetrias políticas, econômicas e jurídicas estabelecidas por/nestas fronteiras, em trânsitos complexos e não lineares.

Desta forma, segundo Neide Lopes Patarra (2006), as novas modalidades migratórias demandam, no cenário da globalização, a necessidade de reavaliação dos paradigmas para o conhecimento e o entendimento das migrações internacionais no mundo; bem como, a incorporação de novas dimensões explicativas torna-se imprescindível, assim como a própria definição do fenômeno migratório deve ser revista.

É imprescindível, ainda segunda a autora, que se considerem, hoje, o contexto de luta e os compromissos internacionais assumidos em prol da ampliação e da efetivação dos direitos dos migrantes, mas é também necessário que se discutam quais os grupos sociais contemplados nas políticas oficiais ancoradas em tais direitos; é preciso reconhecer, nesse contexto, que os movimentos migratórios internacionais representam a contradição entre os interesses de grupos dominantes na globalização e os Estados nacionais, com a tradicional ótica de sua soberania; há que tomar em conta as tensões entre os níveis de ação internacional, nacional e local. Enfim, há que considerar que os movimentos migratórios internacionais constituem a contrapartida da reestruturação territorial planetária intrinsecamente relacionada a reestruturação econômico-produtiva em escala global.

Desta maneira,

[o] entendimento dos processos sociais envolvidos nos fluxos de pessoas entre países, regiōes e continentes passa pelo reconhecimento de que sob a rubrica migração internacional estão envolvidos fenômenos distintos, com grupos sociais e implicações diversas. Se, de um lado, nos interessa reter esse termo como forma de legitimar e garantir a visibilidade do que estamos tratando, nos fóruns internacionais e nacionais, de outro, carregamos o desafio de concretizar, em termos teórico-conceituais, as diversas e complexas interligações de instâncias sociais, econômicas, culturais, jurídicas e institucionais, entre outras, que envolucram os movimentos de pessoas que cruzam fronteiras de Estados-nação (PATARRA, 2006 p.9).

Nas últimas décadas, um número cada vez maior de deslocados forçados em razão de questões ambientais, desastres naturais e mudanças climáticas atravessam fronteiras em necessidade de ajuda humanitária. Na realidade os imigrantes, partem em busca de melhores condições de vida, que podem ou não ser somadas as mudanças ambientais. 
Conforme Larissa Maria Medeiros Coutinho (2015), com a intensificação desse tipo de fluxo migratório, logo surgiram debates acerca do tema e uma tentativa de traçar planos de ação e de proteção específica para esses indivíduos. Para tanto, levantou-se a hipótese de inclusão dos deslocados forçados ambientais no conceito de refugiado. Entretanto, apesar dos esforços de vários internacionalistas, prevalece, até hoje, o entendimento de que os migrantes ambientais não se enquadram na definição jurídica clássica de refugiado prevista no artigo $1^{\circ}$ da Convenção Relativa ao Estatuto de Refugiados de 1951, somado o seu Protocolo Adicional de 1967. Um dos principais argumentos contra a inclusão dos migrantes ambientais no conceito de refugiado é que a configuração do refúgio está intimamente vinculada a duas circunstâncias fundamentais, quais sejam: perseguição materializada e/ou fundado temor à perseguição. Como os indivíduos forçadamente deslocados em razão de questões ambientais, desastres naturais e mudanças climáticas não se encontram em uma situação em que há uma perseguição ou que, pelo menos, haja a demonstração de fundado temor em ser perseguido, resta impossível a concessão de refúgio.

A partir desse panorama, questiona-se: dever-se-ia criar um instrumento jurídico próprio para garantir os direitos dos migrantes ambientais? E atualmente, uma vez que tal instrumento não existe, quais seriam as proteções jurídicas internacionais de que gozam esses indivíduos?

Considerando aqui, como Antonio Augusto Cançado Trindade (1993, p. 135), que "as pessoas deslocadas em diferentes circunstâncias constituem uma categoria que requer cuidadosa atenção e não raro têm maior necessidade de proteção do que os refugiados que deixaram o país", problematiza-se a proteção jurídica internacional de que atualmente gozam esses indivíduos, dando-se especial atenção à solução brasileira da via humanitária complementar aplicada ao caso das migrações haitianas após os terremotos de janeiro de 2010.

\section{O DIREITO DE IR E VIR}

Destacamos que não seria propriamente um direito de ir e vir. Este direito existe no plano nacional, dentro de um mesmo país. Mas quando falamos de movimentos migratórios transnacionais, este direito de ir e vir dos estrangeiros, é limitado pela politica imigratória de cada país. Ao falarmos em movimentos migratórios, não há como fechar os olhos para o desconforto que tal assunto provoca na comunidade internacional, principalmente para com os países mais desenvolvidos e às políticas anti-imigratórias por eles estabelecidas com o claro intuito de impedir ao máximo a entrada de tais estrangeiros em seus territórios, deixando bem claro que os refugiados não são bem-vindos em seus países.

Como exemplo de tais políticas anti-imigratórias pode-se citar o Primeiro-Ministro da Hungria, Sr. Viktor Orbán, que discursou pedindo que os refugiados não viessem a seu país e que ficassem onde estivessem, pois tal fluxo de imigrantes poderia enfraquecer as raízes cristãs na Europa, editando, inclusive, Lei possibilitando a 
prisão dos imigrantes. ${ }^{3}$ Os autores reconhecem da limitação do direito de ir e vir no plano internacional, mormente, na atualidade, com a crise imigratória.

Como se já não fosse suficiente, o governo húngaro está construindo um muro de 4 metros de altura e 175 quilômetros de extensão para fechar suas fronteiras com a Síria.

Tão certo quanto o direito que os Estados possuem para programarem e efetivarem suas políticas públicas e planos de governo, para desenvolvem seus territórios e população, também é inconteste o direito humano mais fundamental, a vida, que deve ser respeitada, não só a dos cidadãos pertencentes aquele território/país, mas como também daqueles imigrantes que buscam o mínimo de dignidade, pois em seus países de origem a simples sobrevivência já não lhe seria garantida.

Assim, na questão migratória, devemos visualizar também o outro lado da moeda, aqueles seres humanos (homens, mulheres, mas principalmente crianças e bebês) que largam tudo - o que já não é quase nada - em seus países de origem, em uma fuga desesperada em busca de um mínimo de vida digna, exercendo o direito de ir e vir, a liberdade de ficar ou não no seu país ou ir para um de sua preferência.

Pois bem, a questão da circulação internacional de pessoas acaba por trazer à baila um confronto entre a política adotada pelo Estado soberano ao controlar o movimento migratório em seu território e o direito internacional que tutela o direito da pessoa humana de ir e vir e seus desdobramentos. Qual deve prevalecer?

Thelma Thais Cavarzere (2001) comenta que o estudo do direito de ir e vir deve realizado com a conciliação de duas concepções aparentemente antagônicas entre si:

1. A concepção de que o indivíduo dispõe de sua própria pessoa, ou seja, é possuidor do direito à autodeterminação pessoal;

2. A concepção de que o Estado deve controlar as migrações dentro de suas fronteiras, seja para impedir o despovoamento, seja para impedir a entrada de elementos perigosos ou desestabilizadores da paz interior da ordem interna desse Estado.

A conciliação das ideias supostamente contraditórias acerca do direito de ir e vir perpassa pela atuação de diversos juristas europeus (como Hugo Grotius, Samuel Pufendorf, Emer de Vattel, dentre outros) ao longo dos séculos XVI a XVIII que já defendiam a liberdade de locomoção, admitindo limitações pelo Estado.

No Brasil, Celso D. de Albuquerque Mello (1982) ressalta a existência de dois princípios: a) admissão do "jus communicationis", que consistiria no direito de emigração e imigração no plano internacional com base na própria necessidade do comércio internacional e na liberdade do indivíduo e; b) direito do Estado de regulamentar a imigração no seu território", o que nada mais seria do exercício da soberania estatal, aduzindo que "as limitações impostas à imigração devem ser genéricas, isto é, sem discriminação de raça, religião e nacionalidade".

${ }^{3}$ Cf. gl.globo.com/mundo/noticia/2015/09/viktor-orban-o-primeiro-ministro-hungaro-vilao-da-crise-migratoria. Acesso 15 vol.09, n. 04, Rio de Janeiro, 2016.pp. 1824-1840 1829 
Assim como os teóricos enfrentavam as nuances do direito de ir e vir e suas implicações, os Estados começaram a positivar o direito de cada um de sair de qualquer país, inclusive o seu, e de a ele retornar, o que pode ser visto a partir da Constituição Francesa de 1791, Assembleia Geral de Frankfurt de 1948 e Ato do Congresso dos Estados Unidos em 1868.

A partir de então começa a surgir a ideia de um mundo sem fronteiras, tendo todos os estados europeus e americanos, excetuados a Rússia, reconhecido o direito de emigrar como básico e alienável.

Observa-se, portanto, que a discussão acerca do direito de ir e vir deixa de ser restrito aos ordenamentos jurídicos dos países individualmente considerados, passando a ter um tratamento global para além das fronteiras nacionais, tendo o Instituto de Direito Internacional recomendado, em 1892, que a livre entrada de estrangeiros não deveria ser restringida, salvo no interesse do bem comum.

Pacifico estava, então, salvo diminutas restrições, a liberdade para a circulação internacional de pessoas, em decorrência do direito à autodeterminação pessoal. Entretanto, todo o direito reconhecido quanto a tal questão fora esvaziado com a Primeira (1914-1918) e Segunda Guerra Mundial (1939-1945), em que pese no período entre guerras alguns acordos bilaterais entre Estados tenham sido realizados, mas sem a força de antes.

Assim, com o fim da Segunda Guerra Mundial, o espirito de liberdade voltou a fazer parte do mundo e, consequentemente, os anseios de protegê-lo, o que inclusive resultou na internacionalização de tais discussões, bem como na criação de organismos internacionais voltados à proteção à paz, ao desenvolvimento mundial e aos direitos humanos, como foi o caso da Organização das Nações Unidas - ONU (1945).

Inobstante a existência de inúmeras normas internacionais versando acerca da livre circulação internacional de pessoas, a Declaração Universal dos Direitos do Homem, de 10 de dezembro de 1948, foi a responsável pela readmissão pelos Estados do princípio da liberdade de circulação internacional do indivíduo, reconhecendo-o como regra jurídica a ser respeitada, que em seu art. 13. Estatuiu:

1.Toda a pessoa tem o direito de livremente circular e escolher a sua residência no interior de um Estado.

2.Toda a pessoa tem o direito de abandonar o país em que se encontra, incluindo o seu, e o direito de regressar ao seu país.

Não há dúvidas de que a Declaração Universal dos Direitos do Homem (1948) reconhece a liberdade de circulação internacional, mas também não há dúvidas de que não é de forma absoluta, pois em seu próprio art. 29 prevê a possibilidade de limitação a tal direito:

1. O indivíduo tem deveres para com a comunidade, fora da qual não é possível o livre e pleno desenvolvimento da sua personalidade.

2. No exercício deste direito e no gozo destas liberdades ninguém está sujeito senão às limitações estabelecidas pela lei com vista exclusivamente a promover o reconhecimento e o respeito dos direitos e liberdades dos outros e a fim de satisfazer as justas exigências da moral, da ordem pública e do bem-estar numa sociedade democrática.

novembro de 2015 . vol.09, nº. 04, Rio de Janeiro, 2016. pp. 1824-1840 
3. Em caso algum estes direitos e liberdades poderão ser exercidos contrariamente e aos fins e aos princípios das Nações Unidas.

Após a Declaração Universal dos Direitos do Homem (1948), outro documento internacional é de suma importância ao estudo do direito de ir e vir, talvez o mais importante, o Pacto Internacional sobre Direitos Civis e Políticos, de 16 de dezembro de 1966, pois se preocupa em detalhar as limitações ao direito de ir e vir, consoante vaticinado em seu art. 12:

1. Todo o indivíduo legalmente no território de um Estado tem o direito de circular livremente e de aí escolher livremente a sua residência.

2. Todas as pessoas são livres de deixar qualquer país, incluindo o seu.

3. Os direitos mencionados acima não podem ser objecto de restrições, a não ser que estas estejam previstas na lei e sejam necessárias para proteger a segurança nacional, a ordem pública, a saúde ou a moralidade pública ou os direitos e liberdades de outrem e sejam compatíveis com os outros direitos reconhecidos pelo presente Pacto.

4. Ninguém pode ser arbitrariamente privado do direito de entrar no seu próprio país.

Segundo o Pacto Internacional sobre Direitos Civis e Políticos o direito de ir e vir não poderá ser restringido, salvo as hipóteses previstas no $\$ 3^{\circ}$ do art. 12, desde que observem o binômio de estar previsto em lei e, ao mesmo tempo, sejam para a proteção da segurança nacional, ordem, saúde, moral pública, ou direitos de liberdade dos outros.

Assim, resta claro que nenhuma das duas concepções, que tivemos com ponto de partida (autodeterminação pessoal e soberania estatal), é rígida, muito pelo contrário, são maleáveis a ponto de permitir uma coexistência, nem tão pacifica quanto se gostaria, mas possível de evolução.

Parece claro que tanto a Declaração Universal dos Direitos do Homem (1948), quanto o Pacto Internacional sobre Direitos Civis e Políticos (1966) visam à proteção a liberdade do indivíduo para ir e vir de seu país, ou seja, põe à disposição o direito de ponderar se quer permanecer, sair e/ou regressar para seu país de origem, o que jamais pode ser confundido com o livre direito de entrar e permanecer em território estrangeiro.

Portanto, o Estado tem o direito de limitar a entrada de estrangeiros imigrantes, vez que apesar do direito de migração decorrer de uma liberdade individual a todos, indistintamente, ainda lhe sobra certa parcela de soberania interna a resguardar a segurança nacional bem como às garantias básicas mínimas aos seus nacionais.

Em que pese o Estado não tenha a obrigação jurídica de admitir estrangeiros, vive-se em um mundo cada vez mais globalizado, em que a comunidade internacional busca uma cooperação entre os países, principalmente os considerados de $1^{\circ}$ mundo, para a redução ou minimização das desigualdades entre os povos e, principalmente, em clara busca ao respeito e reconhecimento aos direitos humanos fundamentais, pelo que se impõe, no mínimo, certa obrigação moral para com aqueles que nada têm e fogem de realidades cruéis como a guerra, fome, miséria, desastres, etc.

Assim, o espírito internacional de cooperação entre os povos clama por um mundo menos indiferente às crises humanitárias daqueles que abandonam suas casas e fogem de seus países em busca de um novo começo para as suas histórias: os refugiados. Precisa-se de um pouco mais solidariedade! 


\section{OS REFUGIADOS}

A circulação internacional de refugiados relaciona-se com o direito de ir e vir e com a violação aos direitos humanos fundamentais daqueles que estão "fugindo". Mas, para que possamos entender o estudo acerca dos refugiados, necessário se faz uma análise da importância da palavra refúgio.

Segundo o Dicionário Aurélio, refúgio (do lat. refugiu) é 1. o local para onde alguém foge a fim de estar em segurança; asilo; abrigo; 2. apoio, amparo, proteção, socorro.

Melhor definição é dada por Georgenor de Sousa Franco Filho (2013, p.207):

Refúgio é o mesmo que esconderijo, local onde nos ocultamos de outros para não sermos vistos ou descobertos. Buscamos refúgio ou esconderijo quando sentimos medo. Medo é causa. Refúgio é consequência. É uma das formas de estudar esse tema: a fuga do medo, a busca de um refúgio para nos esconder do medo.

O homem (ser humano) é um eterno refugiado, eis que o medo sempre esteve e sempre estará presente na história da humanidade, desde os medos mais inocentes que levam uma criança a buscar refúgio nos braços de seus pais, como as fugas de locais infestados por doenças epidêmicas ou mesmo, nos tempos modernos, em busca de refúgio em seu lar doce lar cada vez mais vigiado, trancafiado e enjaulado em face da violência que assola o nosso país.

Partindo da noção de refúgio, agora precisaremos identificar quem são os refugiados.

Não há um consenso doutrinário acerca da definição de refugiado, para tanto, utilizaremos como ponto de partida a Convenção sobre o Estatuto dos Refugiados de 1951 que em seu art. 1º aduz:

Para os fins da presente Convenção, o termo "refugiado" se aplicará a qualquer pessoa que, em consequência dos acontecimentos ocorridos antes de $1^{\circ}$ de janeiro de 1951 e temendo ser perseguida por motivos de raça, religião, nacionalidade, grupo social ou opiniões políticas, se encontra fora do país de sua nacionalidade e que não pode ou, em virtude desse temor, não quer valer-se da proteção desse país, ou que, se não tem nacionalidade e se encontra fora do país no qual tinha sua residência habitual em consequência de tais acontecimentos, não pode ou, devido ao referido temor, não quer voltar a ele.

A referida Convenção foi um instrumento legal internacional criado para estabelecer padrões básicos para o tratamento de refugiados, sem qualquer discriminação por raça, religião, sexo e país de origem.

Além do conceito acima citado, o Estatuto dos Refugiados trouxe o princípio de non-refoulement ("nãodevolução") pelo qual nenhum país pode expulsar/devolver (refouler) um refugiado, contra a vontade do mesmo, para um território onde sofra perseguição.

A evolução do tempo, o fanatismo religioso, além de novas situações geradoras de conflitos e perseguições, fez com que novos fluxos de migrantes precisassem estar sob o manto de proteção da Convenção sobre o Estatuto dos Refugiados de 1951, pelo que se criou o Protocolo relativo ao Estatuto dos Refugiados de 1967. 
Embora o Protocolo esteja relacionado à Convenção de 1951, é um instrumento independente cuja ratificação não é restrita aos Estados signatários da referida Convenção, formando, os dois documentos, os principais instrumentos internacionais relacionados à proteção dos refugiados.

Em novembro de 2007, o número total de Estados signatários da Convenção era de 144 - o mesmo número de signatários do Protocolo de 1967. O número de Estados signatários de ambos os documentos é de 141. O número de Estados signatários de um ou outro documento é de 147. Entre os Estados signatários apenas da Convenção de 1951 estão Madagascar, Mônaco e São Cristóvão e Névis; e entre os Estados signatários apenas do Protocolo de 1967 estão Cabo verde, Estados Unidos da América e Venezuela. ${ }^{4}$

Portanto, considerando os termos da Convenção sobre Refugiados de 1951 e o Protocolo de 1967, na definição de refugiado deve haver a existência de fundado medo de perseguição em virtude de motivos éticos, religiosos ou políticos.

Paulo Borba Casella (2001, p. 23) aponta três tipos de refugiados: os por motivos políticos, que enquadram perfeitamente na definição das Nações Unidas; os por motivos ambientais, são os que recebem menor atenção dos organismos internacionais; e os por motivos econômicos, que possuem a maior dificuldade para definição, chegando, inclusive, a serem confundidos com os migrantes.

No Brasil, a Convenção sobre o Estatuto do Refugiado de 1951 foi implementada definitivamente ao nosso ordenamento jurídico em 22 de julho de 1997, através da Lei no 9.474/97. Diz-se que foi em 1997, pois, embora o país tenha ratificado e promulgado a Convenção de 1951 no ano de 1961 (Dec. 50.215), somente no final da década de 90 criou-se critérios próprios para a concessão do Estatuto do Refugiado, criando-se também o Comitê Nacional para Refugiados - CONARE, responsável pela elaboração de políticas públicas para tal contingente.

Segundo o art. $1^{\circ}$ da Lei 9.474/97, considera-se refugiado:

Será reconhecido como refugiado todo indivíduo que:

I - devido a fundados temores de perseguição por motivos de raça, religião, nacionalidade, grupo social ou opiniões políticas encontre-se fora de seu país de nacionalidade e não possa ou não queira acolher-se à proteção de tal país;

II - não tendo nacionalidade e estando fora do país onde antes teve sua residência habitual, não possa ou não queira regressar a ele, em função das circunstâncias descritas no inciso anterior;

III - devido a grave e generalizada violação de direitos humanos, é obrigado a deixar seu país de nacionalidade para buscar refúgio em outro país.

O que se pode observar da análise do Estatuto dos Refugiados de 1951, do Protocolo de 1967 e da Lei 9.474/97 é que tais diplomas legais se preocupam tão somente com as migrações forçadas tradicionais decorrentes de perseguições de natureza político-ideológica, sem dar maior importância à nova classe de

\footnotetext{
${ }^{4}$ Dados apresentados pelo Alto Comissariado das Nações Unidas para Refugiados em seu site www.acnur.org. Acessado em 07 de
} setembro de 2015 . 
refugiado que surgiu: os ambientais ou climáticos.

Tanto assim é que segundo o Alto Comissariado das Nações Unidas para Refugiados - ACNUR ${ }^{5}$, o Brasil, até outubro/2014 possuía 7.289 refugiados em território nacional, além de 8.302 outras solicitações de refúgios, dados este que não contemplam os nacionais do Haiti, por estes não se enquadrarem na classificação tradicional de refugiado, tendo em vista que a circulação de pessoas não se dá por questões políticas, mas sim por questões ambientais/climáticas.

O refugiado ambiental não saiu voluntariamente de seu país, na verdade ele é um fugitivo com medo da extinção territorial de seu habitat em decorrência de circunstâncias climáticas que o forçaram a buscar outro local para viver ou, no mínimo, sobreviver.

Apesar de tais nacionais solicitarem o reconhecimento da condição de refugiados ao entrarem no território nacional, como sua situação não se amolda ao conceito clássico, as solicitações de "refúgio" são encaminhadas ao Conselho Nacional de Imigração (CNIG) que vem emitindo vistos de residência permanente por razões humanitárias em detrimento das normas internacionais e infraconstitucionais em proteção aos refugiados.

Independentemente dos fundamentos que levam à concessão dos vistos humanitários, é incontroverso o acolhimento dos haitianos no Brasil, pelo que, segundo o Alto Comissariado das Nações Unidas para Refugiados - ACNUR e Policia Federal, entre 2010 e setembro/2014, foram concedidos mais de 39.000 mil vistos nessa modalidade.

No que tange aos centros urbanos, a "acolhida/entrada" no território nacional é garantida, mas a realidade é a falta de espaço para abrigar tantas pessoas, não há comida suficiente, emprego muito menos, saúde não há nem para os brasileiros imagine para os haitianos, ou seja, não se garante o mínimo essencial a viver com dignidade àquele povo já demasiadamente sofrido. Algo há de ser feito.

\section{O MINIMO EXISTENCIAL E A TUTELA COLETIVA}

Um dos pilares de sustentação do Estado Democrático de Direito no Brasil é a ideia de respeito aos direitos fundamentais, dentre eles, o da dignidade da pessoa humana, previsto no art. 10, III da CF/88, a ser observado tanto aos nacionais como aos estrangeiros, em face de igualdade guindada também pelo art. $5^{\circ}$ constitucional.

Como se já não fosse suficiente, ainda temos como um dos objetivos fundamentais da República Federativa do Brasil a promoção dos bens de todos, sem qualquer forma de discriminação, nos termos do art. $3^{\circ}$

${ }^{5}$ Dados apresentados no site: Disponível em: <www.acnur.org> (Estatística - Refúgio no Brasil 2010/2014). Acessado em: 10 de setembro de 2015. 
da Carta Magna.

Pois bem. A norma constitucional traz um núcleo mínimo de direitos sociais necessários para a existência com dignidade, os quais devem ser estendidos a todos, indistintamente.

Ricardo Lobo Torres (2009) entende o mínimo existencial como um conjunto de prestações materiais mínimas necessárias para uma existência digna, variando de uma sociedade para outra.

Para Ingo Sarlet (2015, p. 384) é importante destacar que o mínimo existencial não se confunde com o mínimo vital:

[...] o mínimo existencial abrange não apenas a garantia de sobrevivência física [...] quanto abarca o que se convencionou designar de um mínimo existencial sociocultural [...], incluindo, portanto, o direito à educação e, em certa medida, o próprio acesso a bens culturais.

Entre os direitos mais básicos à uma existência digna, podemos pensar na saúde, educação, moradia, que devem ser concretizados pelo Estado de maneira universal através de políticas públicas a estes "refugiados humanitários" acolhidos em nosso país.

Pois bem, o que vem se observando no dia a dia de tais "refugiados" é que o Estado se preocupa tão simplesmente com a concessão do visto humanitário, mas nega a concretização dos direitos básicos, sob o clássico argumento, já conhecido pelos brasileiros, ainda que em proporções menores se comparadas às dificuldades enfrentadas por estes estrangeiros, da reserva do possível e a impossibilidade de custear o mínimo necessário face às limitações orçamentárias, dentre outras justificativas.

Abrigos existentes na cidade de Brasiléia e mesmo na capital Rio Branco com capacidade para receber 200 refugiados, estavam com aproximadamente 1.000 estrangeiros. A igreja Nossa Senhora da Paz, no centro de São Paulo, improvisou abrigo para acolher 110 haitianos, mas atualmente está com mais de 300. Portanto, em face de grande demanda e a precariedade dos alojamentos, estes haitianos se amontoam no chão, tendo como colchão, um lençol sobre o piso e como travesseiros seus pertences.

Como se já não fosse suficiente, realizam suas refeições ao relento, fazem suas necessidades em banheiros sem qualquer higiene ou privacidade, pois imagine um único banheiro para atender a mais de 100 pessoas.

A assistência médica é inexistente, salvo quando médicos voluntários realizam mutirões para prestar um serviço que seria o mais básico a ser garantido pelo Estado, já resultando inclusive em o óbito de uma haitiana com diagnóstico de pneumonia em Rio Branco/AC.

Ora, se ainda que por questões humanitárias o Brasil "adota" os estrangeiros haitianos, não seria o mínimo, também por questões humanitárias, garantir-lhes uma possibilidade de recomeçar com o respeito aos direitos mais básicos como saúde, educação e moradia? Até mesmo porque não se pode esquecer que tal população abandonou suas raízes (seu país) justamente pelo caos social em que viviam e que não está muito diferente do vivido em nosso país. 
Se aceitamos um hóspede em nossas casas, como anfitriões não devemos assegurar-lhe o mínimo de bem-estar?

É papel do Estado assegurar aqueles direitos mínimos, fundamentais para que as pessoas possam viver e não sobreviver - com dignidade neste país que agora também é destes haitianos aqui acolhidos, até porque é cediço que maior parte dos problemas estruturais do estado brasileiro se dá pela corrupção e má-gestão do dinheiro público.

Se as políticas públicas não são realizadas a contento ou sequer são realizadas, respeitada a real inexistência de recursos financeiros para a concretização dos mandamentos constitucionais, caberia ao Poder Judiciário intervir.

Políticas públicas, segundo Ludmila Fajardo Fassi, seria: um conjunto de metas e diretrizes que orientam a atuação do Poder Público na busca pela efetivação dos chamados direitos sociais, previstos no art. $6^{\circ} \mathrm{da}$ Carta da República, a saber: a educação, a saúde, o trabalho, a moradia, o lazer, a segurança, a previdência social, a proteção à maternidade e à infância e a assistência aos desamparados.

É cediço que o estabelecimento das políticas públicas está a cargo dos Poderes Legislativo e Executivo, entretanto, ao Poder Judiciário, em caráter excepcional, em face da omissão do Estado e da grave violação aos direitos mais básicos que deveriam ser dados aos haitianos aqui acolhidos em razão da concessão de vistos humanitários, caberia impor a adoção de um comportamento positivo pelo Poder Público, a fim de conferir real efetividade aos direitos fundamentais de caráter social, operando uma genuína intervenção concretizadora (ARAUJO, 2010).

Consoante ensinamentos de José Henrique Mouta Araujo (2010), os direitos fundamentais não se repelem, muito pelo contrário, estão se correlacionando e interagindo, e a escolha de um ou de outro a prevalecer em caso de colisão entre eles em determinado caso concreto não importa na exclusão do outro, como se faz na antinomia das normas, mas sim observará um critério de ponderação.

Direitos básicos/mínimos como direito à saúde, à moradia e à vida, além de outros que possam permitir que estes haitianos "em fuga" possam ter o mínimo de dignidade para viver, já que largaram seu país face a tais violações, devem prevalecer e ser garantidos pelo Estado, em patamares satisfatórios, se não através das políticas públicas, através da concretização pelo Poder Judiciário.

Buscar a tutela individual para a concretização de tais direitos mínimos, talvez fosse desprezar a importância ou mesmo a urgência de tal medida, além de se evitar decisões conflitantes entre órgãos judicantes acerca do presente tema, pelo que agir em bloco alcançaria um maior número de beneficiados.

Em face disto, algumas ações coletivas foram intentadas na busca pela efetivação do direito humano de imigrar. 
Na Ação Civil Pública movida pelo Ministério Público Federal e protocolada sob o no 000072355.2012.4.01.3000 perante a 1a Vara Federal (Rio Branco/Acre), foi deferida liminar contra a União para que fossem garantidos direitos humanos dos imigrantes haitianos que vêm ao Brasil em busca de trabalho e condições dignas de sobrevivência, determinando à Polícia Federal não mais barra-los na fronteira. No entanto, a Advocacia Geral da União recorreu ao Tribunal Regional Federal da $1^{a}$ Região que revogou a liminar e, em $1^{\circ} \mathrm{grau}$, em sentença, o magistrado reconheceu a carência da ação relativa ao pedido de auxílio humanitário aos imigrantes haitianos que se encontram no Brasil e julgou improcedente a demanda. $\mathrm{O}$ referido processo ainda aguarda julgamento perante o TRF 1a Região com Recurso de Apelação/Reexame Necessário.

O Ministério Público do Trabalho também ajuizou Ação Civil Pública, protocolada sob o nº 000038481.2015.5.14.0402, em face da União Federal, junto à 2a Vara do Trabalho de Rio Branco/AC, tendo como objeto a promoção de políticas públicas voltadas à proteção dos direitos humanos e fundamentais do trabalhador imigrante e em defesa de direitos difusos e coletivos de toda sociedade brasileira, agindo na conformidade de sua função constitucional preceituada nos artigos 127 e 129 da Constituição Federal de 1988.

Na referida Ação, em 05 de junho de 2015, foi deferida liminar ${ }^{6}$ para a garantia de acomodações dignas, salubres e não degradantes; atendimento médico por profissionais especializados com conhecimento das doenças endêmicas; assunção do fretamento de ônibus e o transporte destes trabalhadores de Brasileia e Assis Brasil até Rio Branco, bem como o transporte interestadual de trabalhadores migrantes para outros Estados da Federação e assunção do serviço de encaminhamento para o emprego (Sistema Nacional de Emprego - SINE), mediante a criação de unidades de atendimento que realizem as atividades necessárias à prevenção da vitimização dos trabalhadores e empregos de qualidade duvidosa.

Observa-se que a demanda coletiva facilita a visualização pelo magistrado da real dimensão do problema "humanitário pátrio", até mesmo porque a necessidade da garantia/respeito aos direitos humanos dos haitianos que se encontram em situação degradante e desumana em nosso país é urgente.

\section{CONSIDERAÇÕES FINAIS}

É cediço que, com base no Estatuto dos Refugiados de 1951 (norma internacional) e na Lei no 9.474/97 (norma interna), os mais de 39.000,00 haitianos que foram recebidos no Brasil não ostentam, pelo menos sob a ótica tradicional, a qualidade de refugiados, tendo em vista que a sua mobilidade se deu em decorrência de desastres ambientais (terremoto em 2010 e furação em 2012) e não por perseguições por raça, religião, nacionalidade, etc., como instituídos pelas normas.

${ }^{6}$ Cf. www.trt 14.jus.br (Acesso 09 de novembro de 2015). vol.09, nº. 04, Rio de Janeiro, 2016.pp. 1824-1840 
Entretanto, tais conceitos precisam ser borrados, alargados, flexibilizados, a fim de permitirem que essa nova modalidade de refugiados, os climáticos ou ambientais, possam ser amparados pelas normas internacionais vigentes para não dependerem única e exclusivamente de ajuda humanitária, como é caso de seu ingresso no Brasil.

E mais, assim como os demais refugiados tradicionais, os haitianos não estão em busca apenas de um território (terra) seguro, livre de desastres naturais, mas sim estão em busca de recomeçar suas vidas com o mínimo de dignidade, o que já não possuíam no Haiti face ao caos que devastou o país.

Buscam um mínimo de educação, saúde, moradia, emprego, direitos sociais estes previstos em nossa Constituição Federal de 1988 aos nacionais e estrangeiros residentes no País (art. $5^{\circ}$ ), o que, entretanto, vem-lhes sendo negado.

Estando o Estado brasileiro em falta com tais direitos prestacionais, busca-se, cada vez mais, o Poder Judiciário, através de sua intervenção concretizadora, a fim de conferir real efetividade aos direitos fundamentais, principalmente através de tutela coletiva protetiva pela Ação Civil Pública.

\section{THE "REFUGEE" HAITIAN AND JUDICIAL INTERVENTION FOR GUARANTEE OF FUNDAMENTAL RIGHTS}

\section{Abstract}

This article aims to analyze the quality of "refugees" of haitians who are in Brazil through the Status of Refugees of 1951 and the Brazilian Law no 9.474/97, proposing a study of the right of movement and the possibility to judicial intervention, through collective action, to guarantee the minimum rights to live with dignity.

Keywords: Migratory movements. Right of movement. Refugees. Fundamental Rights. Existential minimum.

\section{REFERENCIAS}

ACP - AÇÃO CIVIL PÚBLICA protocolada sob o nº 0000723-55.2012.4.01.3000. Ajuizada pelo Ministério Público Federal do Estado do Acre. 26/01/2012.

ACP - AÇÃO CIVIL PÚBLICA protocolada sob o no 0000384-81.2015.5.14.0402. Ajuizada pelo Ministério Público do Trabalho do Estado de Acre. Portaria 218/2014.

ARAÚJO, José Henrique Mouta. Açôes judiciais em defesa dos direitos fundamentais: em busca de solução para os casos concretos. In DIAS, Jean Carlos; KLAUTAU FILHO, Paulo (Coords.) Direitos fundamentais, teoria do direito e sustentabilidade. São Paulo: Método, 2010, pp. 97/105.

BÍBLIA. Bíblia Sagrada. Rio de Janeiro: Enciclopédia Britânica, 1980. 
BRASIL. Constituição (1988). Constituição da República Federativa do Brasil. Brasília/DF: Senado.

Lei 9.474 de 22 de julho de 1997 (Implementação do Estatuto dos Refugiados de 1951).

Lei 11.961 de 02 de julho de 2009 (Dispõe sobre a residência provisória para o estrangeiro em situação irregular no território nacional e dá outras providências).

CASELLA, Paulo Borba. Refugiados: conceito e extensão. In ARAÚJO, Nadia de; ALMEIDA, Guilherme Assis. (Coords.) O Direito Internacional dos Refugiados: uma perspectiva brasileira. Rio de Janeiro: Renovar, 2001.

CAVARZERE, Thelma Thais. Direito Internacional da Pessoa Humana: a circulação internacional de pessoas. 2 eds. Rio de Janeiro: Renovar, 2001.

COUTINHO, Larissa Maria Medeiros. Migrantes ambientais: quem são e como juridicamente protegê-los? In GALINDO, George Rodrigo Bandeira (Org.). Migrações, deslocamentos e direitos humanos. Brasília: IBDC, 2015.pp. 80/91.

FASSY, Ludmila Fajardo. Do controle pelo poder judiciário das políticas públicas em matéria de direitos fundamentais. BDJur, Brasília, DF. Disponível em < bdjur.stj.jus.br>. Acessado em <09 agostos 2015>.

FERREIRA, Aurélio Buarque de Holanda. Novo Aurélio século XXI: o dicionário da língua portuguesa. 3 eds. Rio de Janeiro: Nova Acrópole, 1999.

FRANCO FILHO, Georgenor de Sousa. Refúgios e refugiados climáticos. In Revista de Direito do Trabalho. São Paulo N. 39 (154). nov/dez.2013.pp. 207/213.

FRANGELLA, Simone. O tênue equilibrio no movimento: a vicinalidade na migração transnacional. In Revista de Antropologia. São Paulo: USP, 2014. V 57. N 1.pp. 73/106.

GUIA, Maria João. Imigração e criminalidade: caleidoscópio de imigrantes reclusos. Coimbra: Almedina, 2008.

MARTES, Ana Cristina Braga. Brasileiros nos Estados Unidos: um estudo sobre imigrantes em Massachusetts. São Paulo: Paz e Terra. 1999.

MELLO, Celso D. de Albuquerque. Curso de Direito Internacional Público. Vol. 2. Rio de Janeiro: Freitas Bastos, 1982.

MENEZES, Marilda Aparecida de; GODOI, Emilia Pietrafiesa (Orgs.). Mobilidades, redes sociais e trabalho. São Paulo: Annablume. 2011.

Organização das Nações Unidas. Convenção Relativa ao Estatuto dos Refugiados de 28 de julho de 1951.

Organização das Nações Unidas. Declaração Universal dos Direitos dos Homens de 10 de dezembro de 1948

PATARRA, Neide Lopes. Migrações internacionais: teorias, politicas e movimentos sociais. In Revista Estudos Avançados. 2006. N20.V 5.pp. 7/24.

PEIXOTO, João. As Teorias Explicativas das Migrações: Teorias Micro e Macro-Sociológicas. Publicação Seriada do SOCIUS (Centro de Investigação em Sociologia Econômica e das Organizações do Instituto Superior de Economia e Gestão da Universidade Tecnica de Lisboa). Lisboa: SOCIUS Working Papers. 2004. N 11.

PORTES, Alejandro. Estudos sobre as Migrações Contemporâneas: Transnacionalismo, Empreendorismo e a vol.09, nº. 04, Rio de Janeiro, 2016. pp. 1824-1840 1839 
Segunda Geração. Lisboa: Fim de Século, 2006.

SARLET, Ingo Wolfgang. A eficácia dos direitos fundamentais: uma teoria geral dos direitos fundamentais na perspectiva constitucional. 12 eds. Porto Alegre: Livraria do Advogado, 2015.

TORRES, Ricardo Lobo. O direito ao mínimo existencial. Rio de Janeiro: Renovar, 2009.

TRINDADE, Antônio Augusto Cançado. Direitos Humanos e Meio Ambiente: Paralelos dos Sistemas de Proteção Internacional. Porto Alegre: Fabris, 1993.

Trabalho enviado em 10 de fevereiro de 2016.

Aceito em 31 de maio de 2016. 